\title{
Physicochemical properties of char derived from palm fatty acid distillate
}

\author{
Hamzat Bashir Aderemi a, b, Noor Shawal Nasri c, d, Muhammad Abbas Ahmad Zaini a, c, * \\ a Centre of Lipids Engineering \& Applied Research, Ibnu-Sina Institute for Scientific \& Industrial Research, Universiti Teknologi Malaysia, 81310 \\ UTM Johor Bahru, Johor, Malaysia \\ b Chemical Engineering Department, Kaduna Polytechnic, Kaduna, Nigeria \\ c School of Chemcial \& Energy Engineering, Faculty of Engineering, Universiti Teknologi Malaysia, 81310 UTM Johor Bahru, Johor, Malaysia \\ d UTM-MPRC Institute for Oil \& Gas, Universiti Teknologi Malaysia, 81310 UTM Johor Bahru, Johor, Malaysia \\ * Corresponding author: abbas@cheme.utm.my
}

Article history

Submitted 6 March 2018

Revised 19 March 2018

Accepted 1 April 2018

Published Online 3 September 2018

\begin{abstract}
The present work was aimed to evaluate the physiochemical properties of chars derived from palm fatty acid distillate. The palm fatty acid distillate was heat-treated at $500^{\circ} \mathrm{C}$ and $600{ }^{\circ} \mathrm{C}$ in a muffle furnace for $0.5 \mathrm{~h}$, and the resultant products were characterized for elemental composition, surface functional groups, thermogravimetric profile and methylene blue adsorption. Results show that the char samples are rich in carbon content with unique surface functional groups that could be useful in the liquid-phase adsorption. The solid chars depict a thermally stable profile with the increase of temperature during the heat treatment. The char demonstrated the maximum removal of methylene blue of $7.6 \mathrm{mg} / \mathrm{g}$ and obeyed the monolayer-trend adsorption of Langmuir isotherm. The findings concluded that the palm fatty acid distillate-based char could be an adsorbent candidate for the removal of methylene blue.
\end{abstract}

Keywords: Adsorption, char, methylene blue, palm fatty acid distillate, physicochemical characteristics

(C) 2018 Penerbit UTM Press. All rights reserved

\section{INTRODUCTION}

Textile industries use dyes for beautifications, varieties and aesthetic values of their final products. Methylene blue is a commonly used basic dye for dyeing and other industrial applications. In general, dyes are synthetic in nature and possess complex aromatic molecular structures, inert and not biodegradable (Nasuha \& Hameed, 2011; Hadi et al., 2015). Therefore, the release of dyes into the water streams has become a serious threat to the aquatic environment and public health.

Adsorption is an effective method for dye removal from water, despite the fact that the process is expensive due to the dilemma revolving around adsorbent recycling (Kharub, 2012). The shortfall of this method has led to the quest for potentially more suitable, economical and effective strategies in dye treatment by adsorption process (Gupta \& Suhas, 2009). A number of studies have shown that the industrial by-products such as ash (Woolard et al., 2002), palm oil mill effluent (Yahaya \& Lau, 2013), slag (Ali et al., 2012), palm kernel shell (Garcia et al., 2017) and palm fatty acid distillates (Top, 2010) possess the inherent advantages to be exploited as low cost adsorbents for dye removal. These industrial by-products are generally cheap and abundantly available (Musapatika, 2010). Because of that, the spent adsorbent derived form these materials can be disposed off by incineration (Kong et al., 2014).

Malaysia is the world's second largest producer of crude palm oil. The preferred method in processing palm oil is physical refining to produce refined, bleached and deodorized palm oil products. During physical refining, the fatty acids residue, aldehydes and ketones responsible for the unacceptable odour and flavours are removed by steam distillation under low vacuum (less than 10 torr). The fatty acids vapour leaving the deodorizer is then condensed and cooled (Vijay et al., 2016). This residue is known as palm fatty acid distillate.

Palm fatty acid distillate (PFAD) is a by-product from the refining of crude palm oil. PFAD is a light brown semi-solid at room temperature, and melt to a brown liquid on heating. It comprises mainly of free fatty acid (FFA) (>80\%) with palmitic acid and oleic acid as the major components. The remaining composition includes triglycerides, partial glycerides and unsaponifiable matters, e.g., vitamin E, sterols, squalenes and volatile substances (Ping et al., 2009; Top, 2010). Because of the sub-standard quality and yet with the continuous production, hence large availability, PFAD opens the opportunity to be exploited as useful char adsorbent for dye removal. Therefore, the present work was aimed at evaluating the physicochemical properties of chars and the potential to be used as adsorbent for methylene blue removal.

\section{EXPERIMENTAL}

\section{Materials}

The Palm fatty acid distillate (PFAD) was supplied by IFFCO (M) Sdn Bhd. Methylene blue dye powder $\left(\mathrm{C}_{16} \mathrm{H}_{18} \mathrm{ClN}_{3} \mathrm{~S}\right.$, molecular weight $=319.85 \mathrm{~g} / \mathrm{mol}$, assay $98.5 \%$ ) was purchased from HmbG Chemicals.

\section{Preparation of palm fatty acid distillate-based char}

Desired amount of PFAD was weighed and placed inside a crucible. Then it was introduced into a muffle furnace for heat treatment at $500{ }^{\circ} \mathrm{C}$ and $600{ }^{\circ} \mathrm{C}$ for $0.5 \mathrm{~h}$. The resultant products, designated as $\mathrm{C} 1$ and $\mathrm{C} 2$, respectively, were weighed for yield and were used for physicochemical characteristics and methylene blue adsorption. 


\section{Physicochemical properties of char}

The resultant char samples were characterized for surface function groups using a Fourier transform infrared (FTIR) spectrometer (Spectrum One, PerkinElmer). The thermal stability of the material with temperature was evaluated from room temperature to $900^{\circ} \mathrm{C}$ under the flow of $\mathrm{N}_{2}$ and heating rate of $10^{\circ} \mathrm{C} / \mathrm{min}$ using a thermogravimetric analyzer (Q500, TA Instruments). The elemental composition of PFAD and the resultant chars were determined using elemental analyzer.

\section{Adsorption of methylene blue}

The adsorption of methylene blue onto PFAD-based char was performed for the effects of initial concentration and solution $\mathrm{pH}$. Thirty mg of solid adsorbent was brought into intimate contact with 30 $\mathrm{mL}$ of methylene blue solution of different concentrations $(5-50$ $\mathrm{mg} / \mathrm{L}$ ). Next, the solution mixture was allowed to equilibrate for $72 \mathrm{~h}$. After that, the residual concentration was measured using visible spectrophotometer (Halo Vis-10) at a wavelength of $615 \mathrm{~nm}$. The adsorption capacity, $q_{e}(\mathrm{mg} / \mathrm{g})$ was calculated as, $q_{e}=\left(C_{o^{-}} C_{e}\right) \times V / m$, where $C_{o}$ and $C_{e}(\mathrm{mg} / \mathrm{L})$ are initial and equilibrium concentrations, respectively, $V(\mathrm{~L})$ is the volume of methylene blue solution, and $m(\mathrm{~g})$ is the weight of char.

The effect of $\mathrm{pH}$ on the removal of $20 \mathrm{mg} / \mathrm{L}$ of methylene blue was studied over the $\mathrm{pH}$ range of $3-12$. The $\mathrm{pH}$ was adjusted by adding few drops of $0.01 \mathrm{M} \mathrm{NaOH}$ or $0.01 \mathrm{M} \mathrm{HCl}$ solution. The remaining procedures are the same as described earlier.

\section{RESULTS AND DISCUSSION}

\section{Physicochemical properties of PFAD-based chars}

Table 1 shows the yield and elemental composition of PFAD and the derived chars. The heat treatment of PFAD significantly decreases the yield of char to less than $1 \%$. The effect is more pronounced when the treatment temperature was increased to $600{ }^{\circ} \mathrm{C}$. However, the resultant solids (chars) are purely black, with carbon content of about $85 \%$. It implies the promising application of the material as adsorbent for wastewater treatment.

Table 1 Yield and elemental composition of PFAD-based chars.

\begin{tabular}{|c|c|c|c|c|c|c|c|}
\hline \multirow[t]{2}{*}{ Sample } & \multirow{2}{*}{$\begin{array}{l}\begin{array}{l}\text { Phase } \\
\text { /colour }\end{array} \\
\end{array}$} & \multirow{2}{*}{$\begin{array}{l}\text { Yield } \\
(\%)\end{array}$} & \multicolumn{5}{|c|}{ Elemental composition (\%) } \\
\hline & & & C & $\mathbf{H}$ & $\mathbf{N}$ & $\mathbf{S}$ & $\mathbf{O}^{*}$ \\
\hline PFAD & $\begin{array}{l}\text { Semi- } \\
\text { solid, } \\
\text { brown }\end{array}$ & - & 82.2 & 3.48 & 0.69 & 0.11 & 13.5 \\
\hline $\mathrm{C} 1$ & $\begin{array}{l}\text { Solid, } \\
\text { black }\end{array}$ & $<1$ & 84.4 & 3.85 & 0.06 & 0.19 & 11.5 \\
\hline C2 & $\begin{array}{l}\text { Solid, } \\
\text { black }\end{array}$ & $<1$ & 85.7 & 3.74 & 0.16 & 0.06 & 10.3 \\
\hline
\end{tabular}

${ }^{*}$ calculated by difference

FTIR spectra of PFAD and chars are shown in Fig. 1. The figure sheds light on the unique functional properties of chars from the peaks at different wave numbers. Generally, both $\mathrm{C} 1$ and $\mathrm{C} 2$ display the same peaks which indicates that the samples have practically the same composition of functional groups. This simply means that the increase of temperature in the char production provides trivial effect on the surface functional groups, on top of the decrease in yield. The peaks at around $3840 \mathrm{~cm}^{-1}$ correspond to the $\mathrm{O}-\mathrm{H}$ streching vibrations due to inter- and intra-molecular hydrogen bonding of polymeric compounds (macromolecular associations) such as alcohols, phenols and carboxylic acids. The 'free' hydroxyl groups of PFAD could be due to the presence of free fatty acids, while that of the chars could be associated with the bound water and/or $\mathrm{O}-\mathrm{H}$ functional groups. The peaks at $2840 \mathrm{~cm}^{-1}$ are attributed to the symmetric and asymmetric C$\mathrm{H}$ stretching vibrations of aliphatic acids. Obviously, the peaks disappeared upon the heat treatment at high temperature due to the liberation of fatty acids. The peaks observed at $2660 \mathrm{~cm}^{-1}$ and $2360 \mathrm{~cm}$ ${ }^{1}$ are due to the asymmetric stretching vibrations of $\mathrm{C}=\mathrm{O}$ (carbonic group). Also, the peaks noticed at $2370 \mathrm{~cm}^{-1}$ and $2330 \mathrm{~cm}^{-1}$ could be related to the asymmetric vibrations of triple bond of carbon-to-carbon and carbon-to-nitrogen. The chars also exhibit peaks at $1710 \mathrm{~cm}^{-1}$ and
$1550 \mathrm{~cm}^{-1}$ as a result of the presence of $\mathrm{C}=\mathrm{O}, \mathrm{C}=\mathrm{N}$ and $\mathrm{C}=\mathrm{C}$ groups. The peaks ranging from $1460 \mathrm{~cm}^{-1}$ to $1010 \mathrm{~cm}^{-1}$ indicate the heavy presence of single bond of various functional groups. The peaks at the fingerprint region with wave number lesser than $1000 \mathrm{~cm}^{-1}$ imply the presence of volatile components.

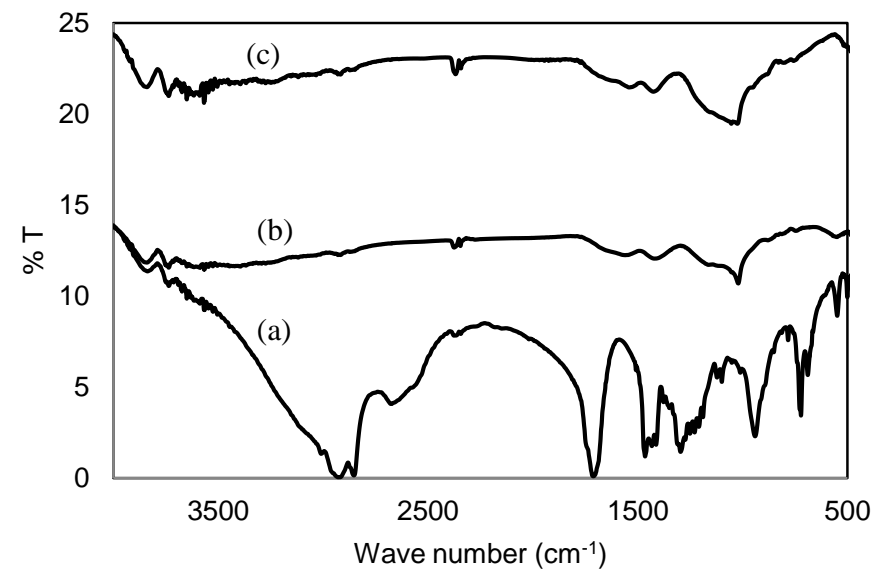

Fig. 1 FTIR spectra of (a) PFAD and PFAD-based chars, (b) C1 and (c) C2.

The thermogravimetric profiles of PFAD and the derived chars are displayed in Fig. 2. PFAD is not thermally stable as it vaporizes at high temperature, and all weight is loss at $500^{\circ} \mathrm{C}$. The sharp peak at $250{ }^{\circ} \mathrm{C}$ could be attributed to the liberation of light free fatty acids and volatiles, while the heavier fractions are released at $350{ }^{\circ} \mathrm{C}$ to $450{ }^{\circ} \mathrm{C}$. On the other hand, the chars, $\mathrm{C} 1$ and $\mathrm{C} 2$, that were prepared from PFAD under the controlled environment are more stable with temperature. The degradation of material as corresponds to the peaks ranging from 500 ${ }^{\circ} \mathrm{C}$ to $700{ }^{\circ} \mathrm{C}$ is due to the burning off of high density carbon structures. As shown in Fig. 2, the thermal stability of $\mathrm{C} 2$ is more pronounced as compared to that of $\mathrm{C} 1$. It is suggested that the building block of $\mathrm{C} 2$ is composed of high density graphitic structure that can withstand high temperature heating.

Equally, there is no significant difference between the physicochemical properties of chars produced from PFAD. As a result, $\mathrm{C} 1$, i.e., the char with a higher yield was considered for further methylene blue adsorption as discussed in the following section.

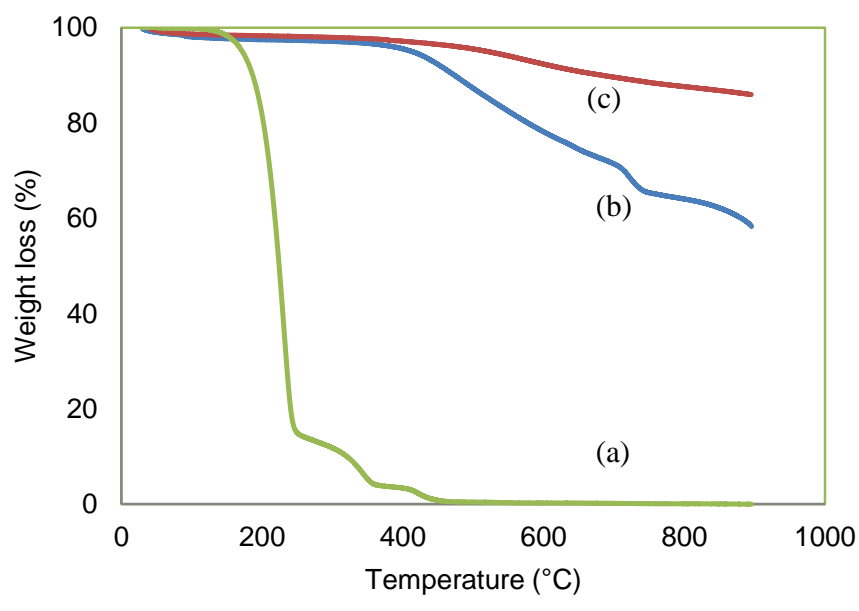

Fig. 2 Thermal profiles of (a) PFAD, (b) C1, (c) C2.

\section{Methylene blue adsorption}

Fig. 3 shows the equilibrium adsorption of methylene blue onto $\mathrm{C} 1$. The isotherm shows a favourable convex upward adsorptive characteristic with a sharp slope at low $C_{e}$ values, to a maximum value of $7.62 \mathrm{mg} / \mathrm{g}$ and then levelling-off. This pattern is common in the dye removal using adsorbents from agricultural and industrial by-products (Aljeboree et al. 2014; Mahamad et al. 2015). The adsorption of methylene blue onto PFAD-char could be promoted by the $\pi-\pi$ 
interaction (weak interaction between aromatic rings of graphitic structure of char and aromatic rings of methylene blue molecules), and the dissociation of acidic oxygenated functional groups to attract the positively charged methylene blue dye molecules. The adsorption data were analyzed using the commonly used isotherm models namely Langmuir and Freundlich. The Langmuir model is given as $q_{e}=Q k_{L} C_{e} /\left(1+k_{L} C_{e}\right)$, where $Q(\mathrm{mg} / \mathrm{g})$ is the maximum capacity and $k_{L}$ $(\mathrm{L} / \mathrm{mg})$ is the adsorption affinity. The Freundlich model is given as $q_{e}=k_{F} C_{e}{ }^{1 / n}$, where $k_{F}$ and $n$ are the Freundlich constants representing the adsorption capacity and adsorption intensity, respectively. The Solveradd in was used to process the data using non-linear regression for the least sum of squared errors (SSE), and the obtained parameters are summarized in Table 2. Clearly, the Langmuir model can adequately describe the adsorption of $\mathrm{MB}$ onto $\mathrm{C} 1$ with the predicted maximum capacity of $6.61 \mathrm{mg} / \mathrm{g}$ at room temperature. The underlying theory of Langmuir equation suggests the monolayer coverage of methylene blue onto the homogeneous surface of $\mathrm{C} 1$. The essential characteristic of this model can be expressed in terms of a dimensionless separation factor, $R_{L}=1 /\left(1+k_{L} C_{o}\right)$ (Mahamad et al., 2015). $R_{L}$ indicates the shape of the isotherm, either unfavorable $\left(R_{L}>1\right)$, linear $\left(R_{L}=1\right)$, favorable $\left(0<R_{L}<1\right)$ or irreversible $\left(R_{L}=0\right)$. Fig. 4 illustrates the profile of $R_{L}$ for methylene blue adsorption onto $\mathrm{C} 1$. The $R_{L}$ values are in the range of $0.013-$ 0.700 , indicating that the adsorption is favorable, in which the process becomes practically irreversible at high initial concentration. The Freundlich model is based on the assumption that the multi-layer coverage onto heterogeneous adsorbent surface. From Table 2 and Fig. 3 , it is evident that the Freundlich isotherm shows a lack of fit because of a greater SSE, and a large deviation from the experimental data, hence it can not be used to represent the adsorption data.

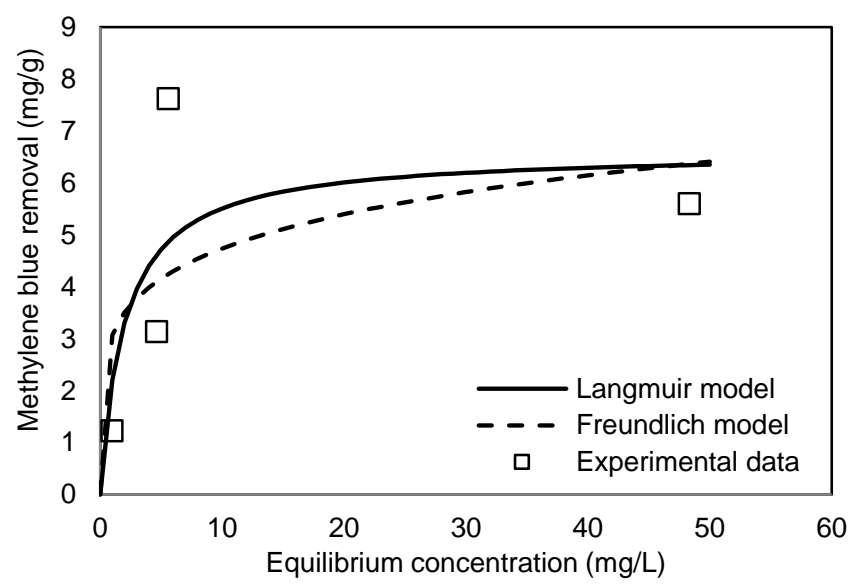

Fig. 3 Adsorption isotherm of methylene blue onto PFAD-based char.

Table 2 Isotherm constants.

\begin{tabular}{ll}
\hline Langmuir model & \\
$Q(\mathrm{mg} / \mathrm{g})$ & 6.61 \\
$k_{L}(\mathrm{~L} / \mathrm{mg})$ & 0.50 \\
$\mathrm{SSE}$ & 11.1 \\
& \\
Freundlich model & \\
$k_{F}(\mathrm{mg} / \mathrm{g})(\mathrm{L} / \mathrm{mg})^{1 / n}$ & 3.07 \\
$n$ & 5.32 \\
$\mathrm{SSE}$ & 16.2 \\
\hline
\end{tabular}

Fig. 5 displays the adsorption of methylene blue onto $\mathrm{C} 1$ at varying solution pHs. From Fig. 5, there was no appreciable change in the degree of adsorption at acidic range of $\mathrm{pH} 2-7$. At this region, the adsorption is restricted, and is apparently to be $\mathrm{pH}$-independent. However, the equilibrium adsorption was found to increase slightly with increasing $\mathrm{pH}$ from $\mathrm{pH} 7$-11, and the methylene blue removal of $7.60 \mathrm{mg} / \mathrm{g}$ was recorded at the $\mathrm{pH}$ range of $10-11$. A methylene bluedeficient adsorption in acidic region is probably due to the presence of excess $\mathrm{H}^{+}$ions competing with the methylene blue cations for the adsorption sites. The decrease in protons concentration at higher solution $\mathrm{pH}$ enables the dye cations to easily lodge on the active sites (Hameed \& El-Khaiary, 2008; Peydayesh \& Rahbar-Kelishami, 2015).

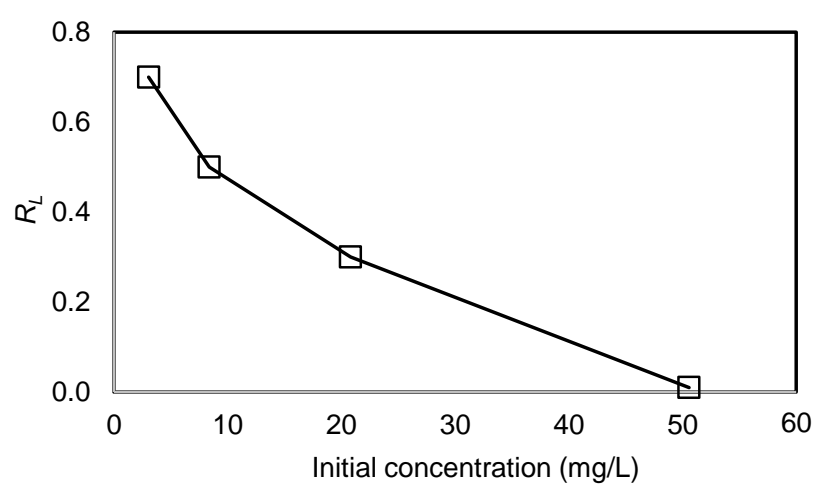

Fig. $4 R_{L}$ profile for methylene blue adsorption onto $\mathrm{C} 1$.

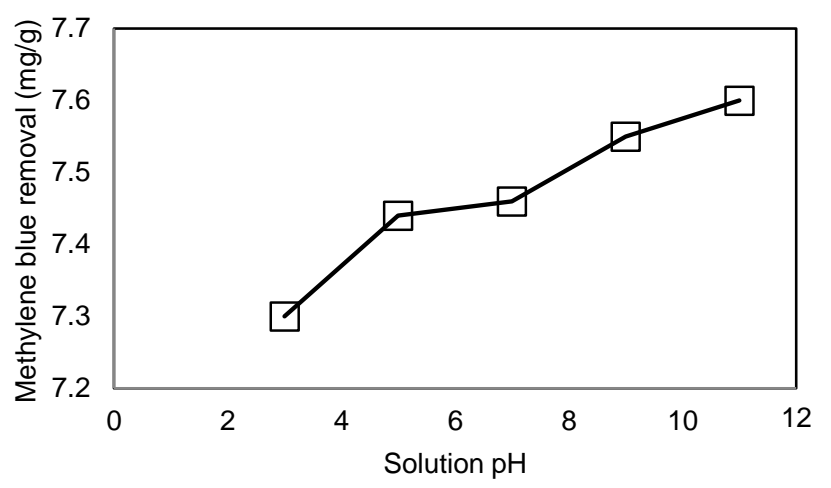

Fig. 5 Adsorption of methylene blue at different solution pHs.

The performance of $\mathrm{C} 1$ in the adsorption of methylene blue was compared with other adsorbents formerly employed for the same application. The information are summarized in Table 3 .

Table 3 Adsorption of methylene blue by various adsorbents.

\begin{tabular}{|c|c|c|}
\hline Adsorbent & $Q(\mathrm{mg} / \mathrm{g})$ & Reference \\
\hline PFAD-based char & 7.62 & This work \\
\hline $\begin{array}{l}\text { sulphuric acid-treated } \\
\text { deffated algae biomass }\end{array}$ & 7.80 & $\begin{array}{l}\text { Sarat-Chandra et al. } \\
(2015)\end{array}$ \\
\hline $\begin{array}{l}\mathrm{KOH} \text {-treated palm oil } \\
\text { mill effluent sludge }\end{array}$ & 23.5 & Zaini et al. (2013) \\
\hline Fly ash & 5.72 & Kumar et al. (2005) \\
\hline Lignocellulosic material & 56.5 & Low et al. (2011) \\
\hline Coir pith carbon & 5.87 & $\begin{array}{l}\text { Kavitha \& } \\
\text { Namasivayam (2007) }\end{array}$ \\
\hline Biochar & 9.50 & Sun et al. (2013) \\
\hline Marble dust sorbent & 16.4 & Hamed et al. (2014) \\
\hline $\begin{array}{l}\text { Food processing } \\
\text { sludge }\end{array}$ & 23.6 & $\begin{array}{l}\text { Mahapatra et al. } \\
(2012)\end{array}$ \\
\hline
\end{tabular}

The PFAD-based char portrays a comparable monolayer adsorption of methylene blue with the adsorbents listed in Table 3. It may be due to its purity and litle or no ash content that ease the adsorption. On the other hand, the other adsorbents demonstrate dissimilar adsorption capacities. This could be due to the nature of the starting materials, carbonization or treatment procedures and the setting conditions for adsorption. This study shows the feasible conversion of PFAD into char or adsorbent, and paves new way for the exploitation of this material in the removal of dye from wastewater.

\section{CONCLUSION}

Palm fatty acid distillate (PFAD) was converted into chars by heat treatment in a muffle furnace at $500{ }^{\circ} \mathrm{C}-600{ }^{\circ} \mathrm{C}$ for $0.5 \mathrm{~h}$. The 
physicochemical properties of PFAD and the derived chars were characterized. The chars are thermally stable at higher temperature as compared to its precursor, PFAD. Also, the chars are rich in carbon content which is likely to be in the graphitized structures, and possess unique functional groups that could be useful in the adsorption of dye. The PFAD-based char show a maximum methylene blue adsorption of $7.62 \mathrm{mg} / \mathrm{g}$, and the experimental data fitted adequately well with the Langmuir model with the predicted monolayer capacity of $6.61 \mathrm{mg} / \mathrm{g}$. There is no appreciable change in the adsorption capacity of methylene blue by PFAD-char at acidic region, while it slightly increased in the basic solution. The results of this study show that the industrial byproduct, namely PFAD can be converted into char as an alternative adsorbent for dye removal from water.

\section{ACKNOWLEDGEMENT}

This work was financially supported by the Universiti Teknologi Malaysia under the Research University Grant (Flagship) \#03G70.

\section{REFERENCES}

Ali, I., Asim, M., Khan, T. A. 2012. Low cost adsorbents for the removal of organic pollutants from wastewater. J. Environ. Manage. 113, 170-183.

Aljeboree, A. M., Alshirifi, A. N., Alkaim, A. F. 2017. Kinetics and equilibrium study for the adsorption of textile dyes on coconut shell activated carbon. Arab. J. Chem. 10, S3381-S3393.

Garcia, J. R., Sedran, U., Zaini, M. A. A., Zakaria, Z. A. 2017. Preparation, characterization, and dye removal study of activated carbon prepared from palm kernel shell. Environ. Sci. Pollut Res. 25, 5076-5085.

Gupta, V. K., Suhas. 2009. Application of low-cost adsorbents for dye removal - A review. J. Environ. Manage. 90, 2313-2342.

Hadi, P., Xu, M., Ning, C., Sze, C., Lin, K., Mckay, G. 2015. A critical review on preparation, characterization and utilization of sludgederived activated carbons for wastewater treatment. Chem. Eng. J. 260, 895-906.

Hameed, B. H., El-Khaiary, M. I. 2008. Batch removal of malachite green from aqueous solutions by adsorption on oil palm trunk fibre: equilibrium isotherms and kinetic studies. J. Hazard. Mater. 154, 237-244.

Hamed, M. M., Ahmed, I. M., Metwally, S. S. 2014. Adsorptive removal of methylene blue as organic pollutant by marble dust as eco-friendly sorbent. J. Ind. Eng. Chem. 20, 2370-2377.

Kavitha, D., Namasivayam, C. 2007. Experimental and kinetic studies on methylene blue adsorption by coir pith carbon, Bioresour. Technol. 98, 1421.
Kharub, M. 2012. Use of various technologies, methods and adsorbents for the removal of dye. J. Environ. Res. Dev. 6, 879-883.

Kong, S. H., Loh, S. K., Bachmann, R. T., Rahim, S. A., Salimon, J. 2014. Biochar from oil palm biomass: A review of its potential and challenges. Renew. Sustainable Energy Rev. 39, 729-739.

Kumar, K. V., Ramamurthi, V., Sivanesan, S. 2005. Modeling the mechanism involved during the sorption of methylene blue onto fly ash. J. Colloid Interface Sci. 284, 14-21.

Low, L. W., Teng, T. T., Ahmad, A., Morad, N., Wong, Y. S. 2011. A novel pretreatment method of lignocellulosic material as adsorbent and kinetic study of dye waste adsorption. Water Air Soil Pollut. 218,293-306.

Mahamad, M. N., Zaini, M. A. A., Zakaria, Z. A. 2015. Preparation and characterization of activated carbon from pineapple waste biomass for dye removal. Int. Biodeterior. Biodegradation 102, 274-280.

Mahapatra, K., Ramteke, D. S., Paliwal, L. J. 2012. Production of activated carbon from sludge of food processing industry under controlled pyrolysis and its application for methylene blue removal. $J$. Anal. Appl. Pyrol. 95, 79-86.

Musapatika, E. T. 2010. Use of low cost adsorbents to treat industrial wastewater. MSc Thesis, University of the Witwatersrand, Johannesburg.

Nasuha, N., Hameed, B. H. 2011. Adsorption of methylene blue from aqueous solution onto $\mathrm{NaOH}$-modified rejected tea. Chem. Eng. J. 166, 783-786.

Peydayesh, M., Rahbar-Kelishami, A. 2015. Adsorption of methylene blue onto Platanus orientalis leaf powder: Kinetic, equilibrium and thermodynamic studies. J. Ind. Eng. Chem. 21, 1014-1019.

Ping, B. T. Y., Yusof, M. 2009. Characteristics and properties of fatty acid distillates from palm oil. Oil Palm Bulletin 59, 5-11.

Sarat-Chandra, T., Mudliar, S. N., Vidyashankar, S., Mukherji, S., Sarada, R., Krishnamurthi, K., Chauhan, V. S. 2015. Defatted algal biomass as a nonconventional low-cost adsorbent: surface characterization and methylene blue adsorption characteristics. Bioresour. Technol. 184, 395-404.

Sun, L., Wan, S., Luo, W. 2013. Biochars prepared from anaerobic digestion residue, palm bark, and eucalyptus for adsorption of cationic methylene blue dye: Characterization, equilibrium, and kinetic studies. Bioresour. Technol. 140, 406-413.

Top, A. G. M. 2010. Production and utilization of palm fatty acid distillate (PFAD). Lipid Tech. 22, 11-13.

Vijay, K. G., Uttara, S., Amrita, B. 2016. Bioconversion technologies of crude glycerol to value added industrial product. Biotechnology Reports 9, 9-14.

Woolard, C. D., Strong, J., Erasmus, C. R. 2002. Evaluation of the use of modified coal ash as a potential sorbent for organic waste streams. Appl. Geochem. 17, 1159-1164.

Yahaya, S. M., Lau, S. 2013. Palm oil mill effluent (POME) from Malaysia palm oil mills: Waste or resource. Int. J. Sci. Environ. Tech. 2, 1138-1155.

Zaini, M. A. A., Zakaria, M., Setapar, S. H. M., Yunus, M. A. C. 2013. Sludgeadsorbents from palm oil mill effluent for methylene blue removal. $J$. Environ. Chem. Eng. 1, 1091-1098. 